\title{
Attention Demands in the Workplace and the Capacity to Direct Attention of Nurses ${ }^{1}$
}

\author{
Alessandra Nazareth Caine Pereira Roscani² \\ Edinêis de Britto Guirardello ${ }^{3}$
}

This was a descriptive, correlational study designed to evaluate the capacity to direct attention (CDA) of the nurse and to verify an association between the CDA and attention demand situations. For data collection the instruments used were: the Attentional Function Index and the Directed Attention Demands. The participants were 169 nurses of a teaching hospital in the State of São Paulo. The mean perception of performance or CDA was 60.4 which differed between the variables: unit of work $(p=0.013)$, work hours $(p=0.044)$, presence of health problems $(p=0.026)$ and problems of a psychological nature $(p=0.005)$. There was a negative association between the situations of demand and CDA $(r=-0.294$, $\mathrm{p}<0.0001)$. It was concluded that nurses showed good CDA, which was related to some professional and demographic variables, and the higher the attentional demands, the lower the CDA.

Descriptors: Nursing; Attention; Health Facility Environment.

\footnotetext{
1 Paper extrated from Master's Thesis "Capacidade de direcionar atenção e demandas de atenção do enfermeiro no ambiente de trabalho" presented to Programa de Pós-graduação em Enfermagem, Faculdade de Ciências Médicas, Universidade Estadual de Campinas, SP, Brazil.

${ }^{2}$ RN, M.Sc. in Nursing, Hospital de Clínicas, Universidade Estadual de Campinas, SP, Brazil. E-mail: alessandra@hc.unicamp.br.

${ }^{3}$ RN, Free Lecture, Associate Professor, Faculdade de Ciências Médicas, Universidade Estadual de Campinas, SP, Brazil. Email: guirar@fcm.unicamp.br.
}

Corresponding Author:

Alessandra Nazareth Caine Pereira Roscani

Rua José Paulino, 1875 Ap. 62B

Vila Itapura

CEP: 13023-102 Campinas, SP, Brasil

E-mail: alessandra@hc.unicamp.br 


\title{
Demandas de atenção no ambiente de trabalho e capacidade de direcionar atenção do enfermeiro
}

Este é um estudo descritivo e correlacional, cujo objetivo foi avaliar a capacidade de direcionar atenção (CDA) do enfermeiro e verificar se há associação entre CDA e as situações de demanda de atenção. Para a coleta de dados foram utilizados os instrumentos: Attentional Function Index e Demandas de Atenção. Participaram do estudo 169 enfermeiros de um hospital de ensino do interior do Estado de São Paulo. A média da percepção de desempenho, ou CDA, foi de 60,4 e diferiu entre as variáveis: unidade de trabalho $(p=0,013)$, carga horária $(p=0,044)$, presença de algum problema de saúde $(p=0,026)$ e problema de cunho psicológico $(p=0,005)$. Existe associação negativa entre as situações de demanda e CDA $(r=-0,294 ; p<0,0001)$. Conclui-se que os enfermeiros apresentaram boa CDA, influenciada por aspectos demográficos e profissionais e que quanto maior as situações de demanda de atenção menor a CDA.

Descritores: Enfermagem; Atenção; Ambiente de Instituições de Saúde.

\section{Demandas de atención en el ambiente de trabajo y la capacidad del enfermero de dirigir su atención}

\begin{abstract}
Se trata de un estudio descriptivo y correlacional que tuvo por objetivo evaluar la capacidad que tiene el enfermero de dirigir su atención (CDA) y verificar se hay asociación entre CDA y situaciones de demanda de atención. Para la recolección de datos se utilizó los instrumentos: Attentional Function Index y Demandas de Atención. Participaron del estudio 169 enfermeros de un hospital de enseñanza del interior del estado de Sao Paulo. El promedio de la percepción de desempeño (CDA) fue de 60,4 y tuvo resultados diferentes entre las variables: unidad de trabajo $(p=0,013)$; carga horaria $(p=0,044)$; presencia de algún problema de salud $(p=0,026)$ y problema de orden psicológico $(p=0,005)$. Existe una asociación negativa entre las situaciones de demanda y CDA $(r=-0,294 ; p<0,0001)$. Se concluye que los enfermeros presentaron buena CDA, la cual es influenciada por aspectos demográficos y profesionales y que cuanto más grandes son las situaciones de demanda de atención, menor es la CDA.
\end{abstract}

Descriptores: Enfermería; Atención; Ambiente de Instituciones de Salud.

\section{Introduction}

The environment of professional nursing practice has been the focus of national and international studies, due to two factors, the first related to the quality of care provided, with the main aspect being patient safety ${ }^{(1-2)}$ and the second, related to the reduction or the shortage of these professionals ${ }^{(3-5)}$.

Nursing is a profession that requires dedication of the individual that is willing to implement it. Besides requiring the scientific and technical knowledge to handle the demands of high complexity and specialization, it calls for the continuous professional development of communication and relationship skills, since it cannot dispense with its affective aspects, sensitivity and interpersonal relationships. It mainly requires physical and psychological skills to meet client needs, initiative and the ability to make quick decisions, which the life of another person often depends on.

The American Association of Critical Care Nursing (AACN) highlights the importance of specialized knowledge, skills and experience to cope with changes arising from the complexity of patient care. It emphasizes that the improvement of the working environment will favor the retention and recruitment of nurses ${ }^{(6)}$.

Nurses, in the exercise of their activities, are faced with multiple situations of attention demand in the environment that require an increase in mental effort 
or capacity to direct attention (CDA) in information processing, decision making and acquisition of new knowledge and skills. The CDA is a kind of selective attention, which requires in individuals the inhibition of distractive, competitive stimuli, as they process and organize important information ${ }^{(7)}$. This is necessary for the effective functioning of daily life, because it allows the person to perceive, think clearly and maintain the intended activity despite distractions in the environment ${ }^{(8-9)}$.

For example, situations involving care of seriously ill patients or those with a risk of imminent death are considered sources of attention demands(10-12) and exposure to these demands can override the CDA, resulting in attention fatigue ${ }^{(7-8)}$, which is manifested as a decreased ability to concentrate, irritability, intolerance, impatience and reduced performance in the management of daily activities.

The theme of attention demands has been addressed in people with health problems ${ }^{(8-9,13-14)}$, the elderly(15), students $^{(16-17)}$ and nurses ${ }^{(10-12)}$. The sources of attention demand of the nurse can be evaluated using a specific instrument, called Directed Attention Demands(10).

It is understood that it is important to identify the different sources of attention demands that the nurse is exposed ${ }^{(12)}$ since the workload and physical and mental attrition, accidents and occupational illnesses and absenteeism are associated with the work environment of these professionals ${ }^{(18-20)}$. However their isolated analysis only allows the recognition of those situations of more or less attention demand. Therefore, studies aimed at evaluating the nurses' perception of performance for attention or CDA are relevant to understanding the influence of these attention demands on the individual's capacity to direct attention.

The motivation for this study arose from professional experience as a nurse in critical care units where, by the very nature of this environment, there is an exposure of the professional to multiple demand situations that influence the ability to maintain focus or concentration on daily activities. Given this, there was a need to evaluate the CDA of nurses and to test the hypothesis that the greater the attention demand situations experienced by nurses, the lower their capacity to direct attention.

It is noteworthy that the imbalance between these variables can cause both personal and professional damage, demonstrating that to understand and reevaluate the context of the work environment of nurses may reflect in better results for care and, consequently, for the institutions it contributes for the managers and administrators in developing strategies that enhance the practice of the professional nurse.

\section{Objectives}

The aim of this study was to evaluate the CDA or perception of performance in the attention of nurses in the workplace and, as secondary objectives: a) to verify if differences exist between the CDA and demographic and professional variables, and b) to verify if association between the CDA and attention demand situations of nurses exists.

\section{Method}

\section{Location of study}

The study was conducted in a teaching hospital, in the state of São Paulo, of tertiary care that gives complex and hierarchical assistance, with a care capacity of 359 beds.

\section{Population and sample}

The study population consisted of 272 nurses who carry out care activities in different shifts of nursing services. The sample consisted of nurses who met the inclusion criteria: a) carry out direct patient care, b) working time at least six months in the institution and c) consent to participate in the study. Those nurses who were absent due to vacation or medical leave and those whose instruments were incomplete or were not returned were excluded from the sample.

\section{Instruments}

Two instruments were used for data collection: the Attentional Function Index $(\mathrm{AFI})^{(17)}$ and the Directed Attention Demands ${ }^{(10)}$.

The AFI aims to subjectively measure how the individual evaluates their performance in certain situations that require concentration or CDA. It consists of 16 items in a visual analogue scale ranging from zero to $100 \mathrm{~mm}$. The score is obtained with the mean of the sum of all items. Values near zero indicate a low perception of performance and values near 100 indicate a high perception of performance. It is an instrument which has good internal consistency, with Cronbach alphas ranging from 0.84 to $0.94^{(8-9,17)}$.

The Directed Attention Demands instrument aims to identify situations of attention demand in the work environment of nurses(10). It is comprised of 39 items grouped into three areas: Physical environment 
(14 items), psychological environment (12 items) and behavioral environment (13 items). There are two types of measures: frequency and intensity, which can be analyzed independently or through a score resulting from the product of both.

The first asks the nurse about the frequency that they have experienced a given situation, using a Likert scale, with five alternative answers ranging from "never, rarely" to "often/all the time." In the second, the nurse is asked to answer how much mental effort is required for that particular situation itself, through a visual analogue type measurement scale, which ranges from zero to 100 millimeters. The score is obtained by the product of frequency by intensity. It is an instrument that also has good internal consistency, with a Cronbach's alpha 0.90 to $0.91^{(10-12)}$.

For this study, the opinion of the professionals was considered, regarding the frequency and intensity of each situation, and calculated as a total score, which takes into consideration the two measures for each situation.

A characterization form was also used containing personal and professional aspects of the nurses, such as: age, sex, marital status, presence of any health problems, length of professional training, professional qualifications, number of employment contracts and weekly working hours.

\section{Procedure}

Initially, project approval was obtained from the Research Ethics Committee of the Faculty of Medical Sciences of UNICAMP. Data collection was performed by one of the researchers, in the period from June to July 2008, during the workday of the nurses with prior consultation of the nursing services work schedules.

Nurses who met the inclusion criteria to participate in the study were informed about the aims and those who agreed were asked to sign the Informed Consent. They were then given the envelope containing the instruments and a copy of the Informed Consent, any doubts were clarified and the location and date for the return of the instruments were set.

\section{Data analysis}

For statistical analysis of the data the program SPSS $^{\circledR}$ (Statistical Package for the Social Sciences) version 15.0. was used. To describe the sample profile, according to the study variables, frequency tables were created of the frequency of the categorical variables and descriptive statistics for the continuous variables. The variable 'presence of any health problem', when described, was related to the variable, 'the presence of disorders of a psychological nature' since these can affect cognitive performance of the individual.

In the comparison of the variables, we used the Chisquare test or Fisher exact test for categorical variables; the Mann-Whitney test for continuous or ordered variables between two groups, and the Kruskal-Wallis between three or more groups. To analyze the variance between instruments and personal and professional variables the analysis of variance (ANOVA) was used, followed by the Tukey's test, when statistical differences were found.

The reliability of the instruments was assessed using Cronbach's alpha, with values above 0.70 being considered as an acceptable level. The Pearson correlation coefficient was used to measure the association between the attention demand situations and the scale of perceived attention performance. The level of significance adopted for the statistical tests was $5 \%$, i.e. $p<0.05$.

\section{Results}

The participants were 169 nurses, mostly female, with a mean age of 40 years, the majority married (43.2\%) and working the night shift (40.2\%). The average time since professional graduation was 16 years, with most (56.8\%) at a Latu sensu (post graduation specialization) level of qualification and with one employment contract $(68 \%)$ (Table 1).

Table 1 - Sociodemographic and professional characteristics of the nurses. Campinas,2009 $(n=169)$

\begin{tabular}{lcc}
\hline \multicolumn{1}{c}{ Characteristics } & \multicolumn{2}{c}{ Sample distribution } \\
\cline { 2 - 3 } Sex & $\mathbf{n}$ & $\%$ \\
Male & 22 & 13.0 \\
Female & 147 & 87.0 \\
Age (years) & & \\
$25-35$ & 56 & 33.1 \\
$36-45$ & 66 & 39.1 \\
$46-55$ & 41 & 24.3 \\
Over 55 & 6 & 3.6 \\
Marital status & & \\
Single & 68 & 40.2 \\
Married & 73 & 43.2 \\
Others* & 28 & 16.6 \\
Year of graduation & & \\
1977-1986 & 36 & 21.3 \\
1987-1996 & 72 & 42.6 \\
1997-2006 & 61 & 36.1 \\
& & Continue...
\end{tabular}


Table 1 - Continuation

\begin{tabular}{lcc}
\hline \multicolumn{1}{c}{ Characteristics } & \multicolumn{2}{c}{ Sample distribution } \\
\cline { 2 - 3 } & $\mathbf{n}$ & $\%$ \\
\hline Professional qualification & 57 & 33.7 \\
Graduate degree & 96 & 56.8 \\
Lato sensu** & 9 & 5.3 \\
Stritcto sensu*** & 7 & 4.1 \\
Others & & \\
Employment contracts & 115 & 68.0 \\
One & 54 & 32.0 \\
Two or more & \\
Work shift & 52 & 30.8 \\
Morning & 49 & 29.0 \\
Afternoon & 68 & 40.2 \\
Night & & \\
*Others: Separated, divorced, widowed, others; $* *$ Lato sensu:Specialization \\
and Residency ***Stricto sensu: MSc/PhD.
\end{tabular}

The average length of time worked in the unit was $9.5( \pm 6.63)$ years and in the institution $13.3( \pm 7.46)$ years. The hours worked in the last week, for the majority, $63(37.3 \%)$, was 36 hours. Another aspect approached with the nurses was related to health problems, noting that $73(43.2 \%)$ reported some type of problem and of these $14(19.2 \%)$ reported problems of a psychological nature.

As regards the CDA of nurses, it was found that the mean of perception of performance of these nurses was 60.4, with means per item ranged from 34.9 to 72.0 (Table 2). In assessing the internal consistency of the instrument, a reliability coefficient of 0.83 was obtained.

Table 2 - Mean and standard deviation of the score given by respondents to situations of perceived attention performance of the nurse. Campinas, $2009(n=169)$

\begin{tabular}{|c|c|c|c|}
\hline Items & Mean & SD* & $\operatorname{Min}-\operatorname{Max}^{* *}$ \\
\hline Finishing things you have started & 72.0 & 21.0 & $0-100$ \\
\hline Make your mind up about things & 71.1 & 19.9 & $2-100$ \\
\hline Keeping you mind on what you are doing & 70.1 & 21.9 & $8-100$ \\
\hline Getting started on activities (tasks, jobs) you intend to do & 69.6 & 20.4 & $14-100$ \\
\hline Planning your daily activities & 69.1 & 21.2 & $0-100$ \\
\hline Keeping track of what you are saying or doing (keeping your train of thought) & 67.7 & 22.8 & $0-100$ \\
\hline Keeping you mind on what others are saying & 66.4 & 22.6 & $0-100$ \\
\hline Following through on your plans & 64.5 & 22.3 & $0-100$ \\
\hline Remember to do all the things you started out to do & 62.9 & 23.9 & $0-100$ \\
\hline Being patient with others & 62.3 & 25.3 & $7-100$ \\
\hline Keeping yourself from saying or doing things you did not want do say or to do & 61.9 & 23.9 & $0-100$ \\
\hline Do things that take time and effort & 60.9 & 23.6 & $0-100$ \\
\hline How hard you find it to concentrate on details & 48.2 & 25.9 & $0-100$ \\
\hline Getting easily annoyed or irritated & 47.5 & 27.8 & $0-100$ \\
\hline Forgetting to do important things & 38.0 & 28.3 & $0-100$ \\
\hline How often you make mistakes on what you are doing & 34.9 & 28.0 & $0-99$ \\
\hline Total & 60.4 & 12.8 & $26,4-92,6$ \\
\hline
\end{tabular}

*SD: Standard Deviation ** Min - Max.: Minimum - Maximum

The perception of attention performance judged by nurses differed between the services $(p=0.013)$, in which nurses from the Medical Surgical Nursing II
Service obtained higher means in relation to the nurses of the Medical Surgical Nursing I Service $(p=0.004)$ and Pediatrics $(p=0.035)$, as shown in Table 3.

Table 3 - Mean and standard deviation of the perception of performance of attention of the nurse by the nursing services. Campinas, 2009 ( $n=169)$

\begin{tabular}{|c|c|c|c|c|}
\hline Service & Mean & SD* $^{*}$ & Minimum & Maximum \\
\hline Medical Surgical Nursing II & 66.5 & 11.0 & 47.9 & 92.3 \\
\hline Referenced Emergency Unit & 64.1 & 13.2 & 44.2 & 92.6 \\
\hline Anesthetic Intensive Care Unit & 63.1 & 17.0 & 40.6 & 91.0 \\
\hline Emergency, Trauma, Bone Marrow Transplant and Psychiatric Nursing & 61.0 & 9.8 & 43.6 & 90.5 \\
\hline Pediatric Intensive Care Unit & 59.3 & 12.6 & 37.6 & 77.6 \\
\hline Intensive Care Unit & 59.1 & 13.8 & 26.4 & 85.5 \\
\hline Pediatric Ward & 54.9 & 12.0 & 32.6 & 77.6 \\
\hline Medical Surgical Nursing I & 54.6 & 13.2 & 32.1 & 79.7 \\
\hline
\end{tabular}

*SD: Standard Deviation. 
By comparing the differences in relation to the perception of performance of attention of nurses and the personal and professional variables, the data indicated differences in the variables 'hours worked last week' and 'health problems'.

The nurses who worked up to 40 hours, judged less perception of performance of attention or CDA in relation to those who worked more than 40 hours $(p=0.044)$, and those who reported a health problem also had lower means of performance of attention $(p=0.026)$ compared to the other nurses. Evaluation of the data of the group of nurses with health problems indicated that those with a problem of a psychological nature showed lower CDA compared to the other nurses $(p=0.005)$.

Evaluating of whether an association exists between the AFI and Directed Attention Demands resulted in a negative association of low magnitude ( $r=-0.294$, $p<0.01$ ) demonstrating that when the situations of attention demand are greater, the CDA is lower.

\section{Discussion}

The study highlights the predominance of women, explained by the sociohistorical trajectory of the profession $^{(21)}$, which corroborates other studies ${ }^{(1,10-11,22)}$. The mean age of the nurses showed a young adult group, which resembles the findings of other studies(11,22). Another important aspect was that in this age group there is a predominance of married nurses, data similar to a national study ${ }^{(23)}$.

The mean length of experience of 16 years corroborates with other studies ${ }^{(2,22)}$ and shows the existence of professionals with extensive experience by staying at the same location, which enables the acquisition of skills necessary for the exercise of the profession. The mean working time in the institution was similar to another study with nurses from the critical care unit(22) and higher than the national studies ${ }^{(11-12)}$.

Furthermore, most have some kind of postgraduation at lato sensu level, with the quest for qualification being a requirement of the labor market that requires professionals with specific knowledge and expertise.

Most nurses have only one employment contract, which is similar to studies with nurses from private institutions $^{(11-12)}$. It is noteworthy that during the study, despite having only one work contract, some nurses reported having carried out more working hours than that established in their labor contract, which can be justified by overtime, resulting from the needs of the service or for an improvement in their salary.

Regarding the measure of perceived attention performance or CDA, the nurses presented a good perception of performance which resulted in a satisfactory level of internal consistency that resembles other studies $(7,9,17,24)$. No studies were found in the literature that could be used for comparison with this study. However, these findings are similar to studies evaluating the CDA with students ${ }^{(16-17)}$ and people with health problems ${ }^{(8-9,13-14,24-25)}$.

It is noteworthy that CDA is essential for nurses in performing activities that require concentration such as planning and giving assistance to the patient and their family, coordinating activities related to their role in the unit as well as to relating with the interdisciplinary team.

An interesting finding was that the CDA of nurses was different among the services because the nurses of the Medical-Surgical Nursing I and the pediatrics service judged lower perception of attention performance in relation to nurses from the other services. The reasons for this finding may be related to the characteristics of a hospital where the patient with high complexity of care is also assisted in other units like no Intensive Care Units that usually did not have the equipment and human resources necessary to attend patients who normally have a high nursing dependency and a risk of instability, as is the case for pediatric, neuroclinical, neurosurgical, traumatological, orthopedic, hematological and nephrological patients.

An unexpected finding was that the nurses who had worked over 40 hours in the previous week reported a higher perception of performance of attention in relation to nurses whose worked less than 40 hours. One of the explanations for this finding may be that the option of performing more hours than their employment contract, aimed at improving personal income, can lead to better planning, organization and consequently personal achievement, which would minimize physical and mental fatigue.

It is noteworthy that the perception of attention performance of the nurse was lower for those with health problems and health problems of a psychological nature, showing their influence on the CDA.

Concerning the hypothesis of a negative correlation between the situations of attentional demands and CDA or perception of performance for attention, this was confirmed, because the greater the situations of demand in the workplace, the lower the CDA or perception of performance of the nurse. 
Faced with these findings, it shows the necessity of the nurses, nursing managers and administrators to adopt strategies to promote positive working environments that minimize situations of attention demand for nurses in their work environment, which will facilitate better attention performance or CDA and consequently improve the assistance provided by this professional.

This study allowed an evaluation of how nurses perceive their performance in situations that require concentration or mental effort. However, a limitation of this study was the impossibility of comparing the measure of perceived performance or CDA with nurses, indicating the need for further related research.

\section{Conclusion}

The study allowed the conclusion that the nurses had a good perception of the attention performance or CDA. But this differed with the nurses of the pediatric and Medical Surgical I services, whose averages were lower than other nurses in other services.
The nurses who worked a weekly workload of less than 40 hours, judged the CDA means lower in relation to nurses with a workload exceeding 40 hours, which was unexpected in this study. The presence of health problems and a condition of a psychological nature also interfered with the CDA of these nurses.

There is a negative association between CDA and attentional demands, i.e. the more attentional demand situations in the work environment of nurse, the lower the perception of performance for activities of quotidian life.

This highlights the importance of the contribution of these findings for future studies, since the situations experienced in the work environment of nurses interfere with their physical and psychological health, and with their performance of activities that require mental effort or an increase in concentration. The findings of this study highlight the need to assess the CDA with other groups of nurses and other health institutions and the importance of comparison with future studies.

\section{References}

1. Aiken LH, Clarke SP, Sloane DM, Lake ET, Cheney T. Effects of hospital care environment on patient mortality and nurse outcomes. JONA. 2009; 39(7/8):45-51.

2. Kutney-Lee A, Lake ET, Aiken LH. Development of the hospital nurse surveillance capacity profile. Res Nurs Health 2009; 32:217-28.

3. Aiken LH, Clarke SP, Sloane DM, Sochalski JA, Busse R, Clarke $H$, et al. Nurse's reports on hospital care in five countries. Health Affairs. 2001; 20:43-53.

4. Mendes IAC, Marziale MHP. Shortage of qualified health workers: a call to action for nurses. Rev. Latino-Am. Enfermagem. março/abril 2008;16(2):171-2. Inglês, Português, Espanhol.

5. Huston $\mathrm{CJ}$. The current nursing shortage: causes, consequences and solutions. In: Huston, CJ. Professional issues in nursing: challenges and opportunities. 2. ed Philadelphia: Lippincott Williams \& Wilkins, 2010. p. 71-91.

6. AACN: Standards for establishing and sustaining healthy work environments: A Journey to Excellence 2005. [Acesso em: Jan 2010]. Disponível em: http://www.aacn.org/aacn/pubpolcy.nfs/ vwdoc/workeny?opendocument.

7. Kaplan S. The restorative benefits of nature: toward an integrative framework. J Environ Psychol. 1995;15(3):169-82.

8. Cimprich B. Attentional fatigue following breast cancer surgery. Res Nurs Health. 1992; 15:199-207.

9. Cimprich B. Age and extent of surgery affect attention in women treated for breast cancer. Res Nurs Health. 1998;21:229-38.

10. Guirardello EB. Adaptação cultural e validação do instrumento demandas de atenção dirigida. Rev Esc Enferm USP. 2005;39(1):77-84.
11. Brito C. Demandas de atenção do enfermeiro de unidades de cuidados críticos. [Dissertação]. Campinas (SP): Universidade Estadual de Campinas; 2006.

12. Santos LSC, Guirardello EB. Nurses' attention demands in the work setting. Rev. Latino-Am. Enfermagem. jan/fev 2007;15(1):27-33. Inglês, Português, Espanhol.

13. Jansen DA, Cimprich B. Attentional impairment in persons with multiple sclerosis. J Neurosci Nurs. 1994;26(2):95-102.

14. Pontes L, Guirardello EB, Campos CJG. Demandas de atenção de um paciente na unidade de transplante de medula óssea. Rev Esc Enferm USP. 2007;41(1): 154-60.

15. Jansen DA. Attentional demands and daily functioning among community-dwelling elders. J Comm Health Nurs. 2006;23(1):113.

16. Tennessen CM, Cimprich B. Views to nature: effects on attention. J Environ Psychol 1995; 15:77-85.

17. Reis CK. Adaptação cultural e validação do Attentional Function Index para cultura Brasileira. [Dissertação]. Campinas (SP): Universidade Estadual de Campinas; 2007.

18. Cavalheiro AM, Moura Junior DF, Lopes AC. Stress in nurses working in intensive care units. Rev. Latino-Am. Enfermagem. jan/fev 2008;16(1):29-35. Inglês, Português, Espanhol.

19. Martins JT, Robazzi MLCC . Nurses' work in intensive care units: feelings of suffering. Rev. Latino-Am. Enfermagem. jan/ fev 2009;17(1):52-8. Inglês, Português, Espanhol.

20. Becker SG, Oliveira MLC. Study on the absenteeism of nursing professionals in a psychiatric center in Manaus, Brazil. Rev. Latino-Am. Enfermagem. jan/fev 2008;16(1):109-14. Inglês, Português, Espanhol. 
21. Padilha MICS, Vaghetti HH, Brodersen G. Gênero e enfermagem: uma análise reflexiva. Rev Enferm UERJ. [internet]. jun. 2006 [acesso em: 20 abril 2009]; 14(2):292300. Disponível em : <http://www.portalbvsenf.eerp.usp.br/ scielo.php

22. Stone WP, Gershon RRM . Nurse work environments and occupation safety in intensive care units. JONA: J Nurs Adm. July/Aug 2009;39(7/8).
23. Stacciarini JNR, Trocolli BT. The stress in nursing profession. Rev. Latino-Am. Enfermagem. março 2001;9(2):17-25. Inglês, Português, Espanhol.

24. Letho RH e Cimprich B. Anxiety and directed attention in women awaiting breast cancer surgery. Oncol Nurs Forum. 1999; 26(4):767-72.

25. Cimprich B, Ronis D. Attention and symptom distress in women with and without breast cancer. Nurs Res 2001;50(2):86-94. 